\title{
THE EVOLUTION AND DESIGN OF POWERS AT THE UN COMMISSION ON HUMAN RIGHTS: THE COMPLEX LEGACY OF ANTI-APARTHEID ACTIVISM
}

\section{FREDERICK COWELL}

BIRKBECK COLLEGE, UNIVERSITY OF LONDON

\begin{abstract}
The development of mechanisms to target specific countries for human rights abuses was part of the campaign against apartheid at the UN in the 1960s. This campaign led to reform of the UN Commission on Human Rights, which turned it from a purely "promotional" or precatory body into one with an active mandate to protect individuals from human rights abuses perpetrated by their own state. The institutional politics of human rights at the Commission was plagued by claims of "double standards" and inter-bloc defensiveness. This article argues that the reform of the Commission in the 1960s and the way that its mechanisms were used in the 1970s defined the Commission's politics in a way that led to its eventual demise in the early 2000 s.

Keywords: apartheid; decolonization; human rights; Third World; UN General Assembly; UN Commission on Human Rights
\end{abstract}

DOI: $10.14712 / 23363231.2019 .17$

Dr Frederick Cowell is a lecturer at the School of Law at the Birkbeck College, University of London. Address correspondence to School of Law, Birkbeck, University of London, Malet Street, LondonWC1E 6DP.E-mail: f.cowell@bbk.ac.uk. 


\section{Introduction}

The history of the UN Commission on Human Rights, which was eventually dissolved in acrimonious circumstances in 2006 and replaced by the UN Human Rights Council, demonstrates how the international campaign against apartheid in South Africa shaped international organizations. The role of the anti-apartheid campaign in driving institutional reform is evident from many General Assembly and Commission on Human Rights resolutions. Collective action by the newly independent states of Africa and Asia, which joined the UN after gaining their independence, led to a reshaping of the institutional structure of the UN Commission on Human Rights and the development of the first "name-and-shame" international mechanism. It also forced the creation of the first mechanism that allowed individuals to directly petition the $\mathrm{UN}$ with claims that their rights were being abused.

The campaign against apartheid is an under-recognized moment in human rights history, which for many years had revolved around highly Eurocentric milestones of intellectual and institutional history. ${ }^{1}$ Samuel Moyn argued that anti-colonialism does not really "fit into" the "historiography of human rights." He saw the African nations' struggle for independence from colonial rule as being outside the Western tradition of civil and political rights, which focused on the rights of the individual rather than collective rights such as national self-determination. ${ }^{2}$ This view has come in for some criticism. Beyond criticizing Moyn, other historians have considered decolonization in the mid-twentieth century as a major historical factor that drove the institutional reform of human rights. ${ }^{3}$ Steven Jensen's history of decolonization, for example, explores how newly

1 For orthodox histories of the treatment of human rights, rooted in the tradition of natural rights, see Lynn Hunt, Inventing Human Rights: A History (London: W. W. Norton \& Company, 2008), 113-145. Institutional histories of human rights often focus on developments at the end of the Second World War. See Mark Mazower, "The End of Civilization and the Rise of Human Rights: The Mid-Twentieth Century Disjuncture," in Human Rights in the Twentieth Century, ed. Stefan-Ludwig Hoffman (Cambridge: Cambridge University Press, 2011), 29. Some have tried to write non-western nations into these accounts of the history of human rights. See Mary Ann Glendon, "The Forgotten Crucible: The Latin American Influence on the Universal Human Rights Idea," Harvard Human Rights Journal 16, No. 1 (2003): 27-39.

2 Samuel Moyn, "Imperialism, Self Determination and the Rise of Human Rights," in The Human Rights Revolution: An International History, ed. Akira Iriye, Petra Goedde, and William I. Hitchcock (Oxford: Oxford University Press, 2012), 159-178, here 160.

3 See Christopher McCrudden, "Human Rights Histories," Oxford Journal of Legal Studies 35, No. 1 (2015): 179-212, doi: 10.1093/ojls/gqu020; See Micheline R. Ishay, The History of Human Rights: From Ancient Times to the Globalization Era (Berkeley: University of California Press, 2004), $173-243$. 
independent states sought substantive changes in the law of human rights and in the way human rights were treated in international relations. ${ }^{4}$ From 1962, Jensen argues, respect for human rights law became important for the development of friendly relations between states, and resulted in the Helsinki Final Act of the Conference on Security and Cooperation in Europe in the 1970s. ${ }^{5}$ These historical accounts have not focused much on the way the powers of relevant UN bodies evolved. Institutional histories of the UN have mentioned the campaign against apartheid that dominated the UN General Assembly for much of the 1970s, but only in passing. ${ }^{6}$ Other histories view the anti-apartheid campaign as more central to the history of the UN, but they have not offered a detailed analysis of its impact on the UN's institutional development. ${ }^{7}$

This article argues that the campaign against apartheid by the newly independent states resulted in institutional changes in the way the UN Commission on Human Rights operated, empowering it to investigate human rights abuses in various countries and allowing individuals to petition the Commission for redress of human rights abuses from which they were suffering. The Commission was originally created with an explicitly limited set of powers that did not include investigating human rights abuses. As the first two sections of this article describe, new mechanisms at the Commission emerged in response to apartheid, giving it broader powers.

The "rational design" theory of international organizations maintains that states construct international institutions in order to advance certain common goals. The design of the institutional structures then authorizes or encourages specific behaviors. ${ }^{8}$ This is different from the "rational institution" analysis of international organizations, which sees such organizations as helping states maximize their individual interests. The latter analysis focuses on how states use organizations for their own ends, rather than how an organization's powers are shaped. ${ }^{9}$ As Barbara Koremenos summarizes it, rational design theorists exam-

4 Steven Jensen, The Making of International Human Rights: The 1960s, Decolonization, and the Reconstruction of Global Values (Cambridge: Cambridge University Press, 2016).

5 Ibid., 3-11.

6 See Meisler's work, which contains just three references to apartheid: Stanley Meisler, United Nations: A History, 2nd ed. (New York: Grove Press, 2011).

7 See, for example, Saul Dubow, "Smuts, the United Nations and the Rhetoric of Race and Rights," Journal of Contemporary History 43, No. 1 (2008): 45-74, doi: 10.1177/0022009407084557.

8 Barbara Koremenos, Charles Lipson, and Duncan Snidal, "The Rational Design of International Institutions," International Organization 55, No. 4 (2001): 761-799.

9 Kenneth W. Abbott and Duncan Snidal, "Why States Act through Formal International Organizations," The Journal of Conflict Resolution 42, No. 1 (1998): 3-32. 
ine how "states and other international actors shape institutions to solve the specific cooperation problems that they face," meaning that "design variations are largely the result of rational, purposeful interactions." 10 As the second section of this article argues, the new mechanisms the Commission developed in the 1960s were specifically designed as a response to apartheid in South Africa. That meant that the Commission ran into difficulty when these mechanisms were invoked outside of the South African context in the 1970s and 1980s.

The latter parts of this article argue that at the Commission in the 1970s, states from different geographic and ideological groupings stymied the further use of its powers. What were called at the time "double standards" on human rights emerged in part because of the way Commission procedures were designed. Apartheid was framed as an impediment to post-colonial self-determination, not as an abuse of basic human rights. This meant that equivalent situations outside of South Africa were ignored or blocked from consideration, as can be seen from numerous contemporary accounts of the Commission's work, some of which are discussed below. The Commission found that its investigative powers were caught up in Cold War power politics, and its ability to consider petitions from individuals was subject to the control of states voting in blocs. This had long-term consequences.

By the late 1990s, the Commission was being widely criticized for its ineffectiveness and politicization, and for the way influential states could block scrutiny of their allies. For example, by 2000 China had escaped censure of its human rights record several times, by relying on the protection of its allies, often secured by providing economic inducements to other states to support its positions. The 1989 Tiananmen Square massacre was never even considered by the Commission. ${ }^{11}$ In a 2001 New York Times editorial, the Director of Human Rights Watch criticized the way "the world's despots and tyrants" were able to "join the commission to protect themselves from criticism and to undermine its work." 12 This article argues that one of the underdiscussed causes of the "credibility crisis" that crippled the Commission in its later years was the way the Commission's powers

${ }^{10}$ Barbara Koremenos and Allison Nau, "Exit No Exit," Duke Journal of Comparative and International Law 21, No. 2 (2010): 81-119, here 86, https://scholarship.law.duke.edu/cgi/viewcontent .cgi ?article $=1033 \&$ context $=$ djcil.

11 Penny Parker and David Weissbrodt, "Major Developments at the UN Commission on Human Rights in 1991," Human Rights Quarterly 13, No. 4 (1991): 573-613, doi: 10.2307/762307; Michael Dennis, "Recent Developments: The Fifty-Sixth Session of the UN Human Rights Council," American Journal of International Law 95, No. 1 (2001): 213-221, doi: 10.2307/2642062.

12 Kenneth Roth, "Despots Pretending to Spot and Shame Despots," New York Times, April 17, 2001, http://www.nytimes.com/2001/04/17/opinion/17iht-edroth_ed2_.html. 
and procedures were designed and the way they shaped some states' behavior. ${ }^{13}$ Even though much of this happened in the 1970s, it established a set of expectations surrounding the Commission's operations which was to persist for the rest of its lifetime.

\section{The Commission on Human Rights and the Context of its Powers in the UN}

When the UN Charter was being drafted, western states were hostile to the idea of an independent human rights mechanism. The British and Australians successfully blocked proposals by the Philippines and Chile at the 1945 San Francisco conference to create an independent investigative organization with its own bill of rights. ${ }^{14}$ The Commission on Human Rights was set up in 1946 as a sub-body of the UN Economic and Social Council (ECOSOC). Its membership was decided upon by a "slate vote" of ECOSOC members, which meant that a list of countries proposed for membership by each of the UN's regional groupings was automatically approved by the other states. The Commission met annually in Geneva for six weeks. It was what legal scholars classify as a "political" organization in that it was comprised of state representatives, rather than independent experts, and depended on political processes and pressure rather than international legal obligations to guide its decisions. ${ }^{15} \mathrm{~A}$ sub-commission of the Human Rights Commission on the Prevention of Discrimination and Protection of Minorities (the Sub-Commission) was set up in 1947 to conduct studies and make recommendations to the Commission on preventing discrimination against minorities. It was comprised of twelve independent experts selected by the Commission, who were expected to act in their individual capacities, making it an expert, not a political body. In its first decade, the Commission spent much of its time drafting human rights covenants which turned the Universal Declaration of Human Rights (UDHR) into two binding international treaties: the International Covenant on Civil and Political Rights (ICCPR) and the International Covenant on Economic, Social and Cultural Rights (ICESCR).

${ }^{13}$ For this description of the Commission see Helen Upton, "The Human Rights Council: First Impressions and Future Challenges," Human Rights Law Review 7, No. 1 (2007): 29-39, doi: 10.1093/ $\mathrm{hrlr} / \mathrm{ngl031.}$

14 Tom J. Farer, "The United Nations and Human Rights: More than a Whimper Less than a Roar," Human Rights Quarterly 9, Vol. 4 (1987): 550-586, here 555.

${ }^{15}$ Laurence R. Helfer and Anne-Marie Slaughter, "Toward a Theory of Effective Supranational Adjudication,” The Yale Law Journal 107, No. 2 (1997): 273-392, https://digitalcommons.law.yale .edu/ylj/vol107/iss $2 / 1$. 
The Commission did accept complaints from individuals, but they had to be reviewed in complete confidence with no follow up action allowed. Most of these complaints took the form of petitions from individuals pleading in general terms for UN assistance. Information about the complaints received between 1951 and 1952 shows that the majority were from refugees from Eastern Europe who were concerned with religious liberties or political freedoms. ${ }^{16}$ Nothing could be done about these complaints, however, and they simply piled up at the UN's headquarters. In a 1951 article, Edgar Turlington, an American academic, described the Commission's functions as advancing the values contained in the UDHR by "teaching and education and by progressive measures." 17 In the mid1950s, a variety of proposals to expand the UN's power to enforce human right standards were mooted, including a proposal from Sri Lanka to create an international criminal court and from Uruguay to create a UN Attorney-General. ${ }^{18}$ The United States proposed some reforms to the Commission but these were dismissed by contemporary commentators as a "euphemism for inaction" driven by short-term political motivations. ${ }^{19}$ ECOSOC Resolutions in 1947 and 1959 on handling individual petitions affirmed that the Commission had "no power to take action," leaving the Commission and the Sub-Commission with no mechanism at all to advocate for or protect human rights within member states. ${ }^{20}$

Prior to the late 1950s, African and Asian states were under-represented on the Commission, and colonies had no representation in the UN at all. From the late 1950s onwards, decolonization resulted in more states from Asia and Africa joining the UN. These newly independent states required a collective grouping to assert their own identities and promote their own policy agendas at the UN, where many crucial institutions were dominated by the former colonialist states. ${ }^{21}$ This grouping came to be known as the Third World bloc - although the use of the term "Third World" has been the subject of fierce debate because it has connotations of underdevelopment and inferiority and can be interpreted

${ }^{16}$ John P. Humphrey, Human Rights and the United Nations: A Great Adventure (New York: Transnational Publishers, 1984), 20.

17 Edgar Turlington, "The Human Rights Commission at the Crossroads," American Journal of International Law 45, No. 3 (1951): 534-538.

18 Howard Tolley, United Nations Commission on Human Rights (Boulder: Westview Press, 1987), $32-34$.

19 Norman Bentwich, "Human Rights in the Doldrums," Contemporary Review No. 1088 (1956): 76, 79.

${ }^{20}$ Manfred Nowak, "The Promotion and Protection of Human Rights by the United Nations," Netherlands Human Rights Quarterly 6, No. 1 (1988): 5-29, here 13.

${ }^{21}$ Mohammed Ayoob, "The Third World in the System of States: Acute Schizophrenia or Growing Pains?" International Studies Quarterly 33, No. 1 (1989): 67-79, doi: 10.2307/2600494. 
as a semiotic endorsement of western supremacy. ${ }^{22}$ The term "Third World" was first used in 1952 by Alfred Sauvy, the director of France's Institut National d'Études Demographiques. It was later popularized by the anti-colonialist scholar Frantz Fanon in his book, The Wretched of the Earth. ${ }^{23}$ The 1955 Bandung Conference saw an early restatement of the collective ideology of what would later become the Third World bloc at the UN. At the conference, the Indian Prime Minister, Jawaharlal Nehru, stated that "Asia and Africa must play an increasing role in [the UN's] conduct and destiny." The final communiqué called for the newly independent states of Africa and Asia to be admitted to the UN and to be granted an "equitable geographical distribution" of Security Council seats. The communique situated institutional reform at the heart of the policies promoted by what would later become the Third World bloc. ${ }^{24}$

In order to promote equal representation as its membership was rapidly increasing, the UN established a system of regional groupings in 1963. The largest wave of new entrants to the UN came between 1959 and 1962 as a result of decolonization in Africa. The system of regional groupings, which is still in existence today, divides UN member states into five geographic blocs: African, Asian, Latin American and Caribbean, Eastern Europe, and Western European and Other (a designation that includes North America). Member states from the blocs each control a proportion of the positions on UN bodies. Blocs often acted collectively, voting along common ideological lines in the General Assembly and in other UN bodies. Postcolonial states mostly belonged to the African and Asian blocs, while the former colonialist states generally belonged to the Western and Other bloc. The "Third World" bloc, as it came to be called, was an ideological grouping that consisted of the African and Asian blocs along with other states that occasionally shared its priorities. There are a wealth of contemporary sources that show that in the 1960s and 1970s the term "Third World" was used interchangeably with other names such as the "Group of 77" and the "Non-Aligned Movement" to describe the bloc of newly decolonized states in various UN bodies. Some historians have argued that the term "Third World

22 Arturo Escobar, Encountering Development: The Making and Unmaking of the Third World (New Jersey: Princeton University Press, 1995), 21-54.

23 Bernard Greene, "Toward a Definition of the Term the Third World," Boston College Third World Law Journal 1, No. 1 (1990): 23-37.

24 Vijay Prashad, The Darker Nations: A People's History of the Third World (New York: The New Press, 2007), 41; Final Communiqué of the Asian-African Conference of Bandung 24th April 1955, para F1, http://franke.uchicago.edu/Final_Communique_Bandung_1955.pdf; Carlos Rangel, Third World Ideology and Western Reality: Manufacturing Political Myth (New Jersey: Transaction Books, 1986), 43. 
bloc" can be used to describe the shared ideological agenda of African and Asian states at the UN during this period. Hence the term "Third World bloc" was used to describe the ideological alignment of states from the African and Asian geographic blocs at the UN, rather than the term "Third World state," which would reinforce inequality and colonial-era presumptions of inferiority. ${ }^{25}$

\section{How the Third World Bloc's Anti-Apartheid Campaign Reshaped the Commission}

The struggle against apartheid was one of the core issues on the Third World bloc's agenda. South African apartheid first came before the UN in 1946, when the General Assembly voted in favor of a resolution demanding that South Africa treat its Indian citizens in conformity with the UN Charter. ${ }^{26}$ The South African prime minister, Jan Smuts, argued that UN members had no obligations in regard to the protection of human rights that required the South African government to abolish apartheid. Between 1952 and 1954, the General Assembly repeatedly condemned apartheid as a form of racial discrimination contrary to the "higher interests of humanity." It authorized the creation of an expert commission to investigate the situation relating to apartheid, but little came of such declarations. ${ }^{27}$ Broadly speaking, the overall thrust of the General Assembly in the 1950s was to initiate a dialogue with the South African government to address the problems caused by apartheid laws, rather than exert some form of overt political pressure or condemn apartheid as a violation of international human rights standards. ${ }^{28}$ Still, the South African government refused to engage

25 Prashad, Darker Nations, xv.

26 "Treatment of Indians in the Union of South Africa," Resolution No. 44 (I), adopted by the General Assembly, 1st session, December 8, 1946, https://undocs.org/en/A/RES/44(I).

27 "The question of race conflict in South Africa resulting from the policies of apartheid of the Government of the Union of South Africa," Resolution No. 616 (VII), adopted by the General Assembly, 7th session, December 5, 1952, https://www.un.org/en/ga/search/view_doc.asp?symbol=A/2361\%20(supp), 8-9; "The question of race conflict in South Africa resulting from the policies of apartheid of the Government of the Union of South Africa," Resolution No. 820 (IX), adopted by the General Assembly, 9th session, December 14, 1954, https://www.un.org/en/ga /search/view_doc.asp?symbol=A/2890\%20(supp), 9; "The question of race conflict in South Africa resulting from the policies of apartheid of the Government of the Union of South Africa," Resolution No. 917 (X), adopted by the General Assembly, 10th session, 1955, December 6, https:// www.un.org/ga/search/view_doc.asp?symbol=A/3116(supp), 8.

${ }^{28}$ Newell M. Stultz, "The Apartheid Issue at the General Assembly: Stalemate of Gathering Storm," African Affairs 86, No. 342 (1987): 25-45, here 29. 
with the UN, claiming that any UN action constituted an interference with their sovereignty.

At the beginning of the $1960 \mathrm{~s}$, three things escalated the severity of the UN's approach towards apartheid. Firstly, African nations that had gained independence, in particular Ghana, took seats in the UN and began to advocate strongly for harsher sanctions against apartheid. ${ }^{29}$ Secondly, General Assembly Resolution 1514 established the general principle of support for decolonization in international law. It was based on a general sense that minority rule in Africa was illegitimate from both a moral and legal perspective. ${ }^{30}$ Finally, the events of early 1960 - British Prime Minister Harold Macmillan's "winds of change" speech, where he called on governments not to stand in the way of decolonization, and the massacre of protestors at Sharpeville in South Africa - led to increased criticism of South Africa.

General Assembly Resolution 1699 created a special committee for territories under Portuguese rule. In 1962, the General Assembly, after examining reports from this committee, passed a resolution "deploring the continued disregard by the Portuguese Government" for the liberation aspirations of the people in its African colonies. The General Assembly urged all states "to refrain forthwith ... from any assistance which would enable it to continue its repression." ${ }^{11}$ Some authors argue that General Assembly Resolution 2144 in 1966 was the turning point. It urged ECOSOC and the Commission to improve the UN's capacity to prevent human rights violations. ${ }^{32}$ Resolution 2144 was specifically framed in terms of the UN's "interest in combating policies of apartheid" and the preamble referred extensively to apartheid, minority rule and Portuguese colonialism. ${ }^{33}$ Nine of the fourteen substantive points in the resolution

${ }^{29}$ Christable Gurne, “'A Great Cause': The Origins of the Anti-Apartheid Movement, June 1959 March 1960," Journal of Southern African Studies 26, No. 1 (2000): 123-144, here 127-128, doi: $10.1080 / 030570700108414$.

30 The UN had become distinctly anti-colonial by 1965. See Rupert Emerson, "Colonialism, Political Development and the UN," International Organization 19, No. 3 (1965): 484-503.

31 "Territories under Portuguese administration," Resolution No. 1807 (XVII), adopted by the General Assembly, 17th session, 1962, December 14, https://www.un.org/ga/search/view_doc.asp?symbol=A/5217(supp), 39-40.

32 Bertrand Ramcharan, Contemporary Human Rights Ideas: Rethinking Theory and Practice (Oxford: Routledge, 2008), 131-132.

33 "Question of the violation of human rights and fundamental freedoms, including policies of racial discrimination and segregation and of apartheid, in all countries, with particular reference to colonial and other dependent countries and territories," Resolution No. 2144 (XXI), adopted by the General Assembly, 21th session, October 26, 1966, https://www.un.org/ga/search/view_doc .asp? symbol=A/6316(SUPP), 46-47; Newell M. Stultz, "Evolution of the United Nations Anti-Apartheid Regime," Human Rights Quarterly 13, No. 1 (1991): 1-23, doi: 10.2307/762456. 
referenced apartheid and anti-colonialism. Only three of them referred, directly or indirectly, to the protection of human rights.

The anti-apartheid campaigns of the Third World bloc also had an impact on the rapid advancement of anti-racism measures in international human rights law, which culminated in the 1965 Convention on the Elimination of All Forms of Racial Discrimination (CERD). The 1963 General Assembly Resolution on the Elimination of All Forms of Racial Discrimination built on CERD, advocating independence for peoples living under colonial rule and condemning the racial discrimination underlying colonialism. It was strongly supported by states from the Third World bloc. ${ }^{34}$ The speed with which CERD entered into force - it took less than four years for enough states to ratify the treaty for it to take effect - was indicative of the success of the concerted campaign run by the Third World bloc to enact CERD. ${ }^{35}$ At the Commission, one major priority of the newly independent states was including the right to self-determination into the two human rights covenants - the ICCPR and the ICESCR. The covenants gave the right to be free of colonialism that was embodied in General Assembly Resolution 1514 additional legal force. By the late 1960s, the number of states in the Third World bloc had increased in all UN institutions. The political focus shifted to institutional reforms, which altered both the nature of the Commission and enhanced institutional opposition to apartheid overall.

\section{Institutionalizing Anti-Apartheid: The 1235 Procedure}

The first major reform of an existing institution that resulted from the Third World bloc's campaign against apartheid was ECOSOC Resolution 1235, passed in August 1967. The request to ECOSOC for action came from the Commission in early 1967. It was based on an expert report presented at the Commission's 23rd session, which was strongly supported by the Third World bloc states. ${ }^{36}$ Under the final version of Resolution 1235, the Commission and the Sub-Commission were empowered to consider "violations of human rights ... including policies of racial discrimination and segregation and of apartheid" along with the power to

\footnotetext{
34 “United Nations Declaration on the Elimination of All Forms of Racial Discrimination," Resolution No. 1904 (XVIII), adopted by the General Assembly, 18th session, November 20, 1963, https://undocs.org/en/A/RES/1904(XVIII).

35 Theodor Meron, "The Meaning and Reach of the International Convention on the Elimination of All Forms of Racial Discrimination," American Journal of International Law 79, No. 2 (1985): 283-381, here 284, doi: 10.2307/2201704.

36 Tolley, “United Nations Commission," 56.
} 
investigate and study specific "human rights abuses." 37 While it seemed inconsequential, the resolution for the first time granted the Commission the power to single out a specific state for committing human rights abuses against its own citizens. ${ }^{38}$ It is debatable whether the reference to apartheid was meant to limit the procedure to human rights abuses in South Africa or whether this was merely an illustration of a situation where the Commission should act. ${ }^{39}$ Article 3 of Resolution 1235 stated that the Commission's investigatory powers were confined to cases such as those "exemplified by the policy of apartheid as practised in the Republic of South Africa." ${ }^{40}$ Except for one reference in paragraph 5, which stated that the new powers were meant to assist the Commission in "discharge[ing] functions in relation to violations of human rights and fundamental freedoms," all of the other references to human rights in the text of Resolution 1235 linked their protection to "the policy of apartheid as practiced in the Republic of South Africa and in the Territory of South West Africa." ${ }^{11}$

During the drafting process, Cameroon and Algeria had sided with the USSR, which argued that resolution should be limited to situations of colonial rule, but the final wording seemed to use apartheid as an inclusive, not an exclusive term. Nevertheless, the phrasing of the provision, in particular the specificity of the location the abuses - "the Republic of South Africa and in the Territory of South West Africa" - meant that some states could argue that investigations should not occur outside of that context. Resolution 1235 was still seen by some contemporary authors as a significant step forward, which allowed the consideration of human rights abuses in other countries. In October 1967, it was used to discuss the situations in Greece and Haiti. ${ }^{42}$ Other authors have considered 1235 as the start of a process of institutional reform at the Commission, which began to move it toward an institutional system for protecting individual rights. ${ }^{43} \mathrm{It}$

37 Ibid.

38 See Conall Mallory, "Membership and the UN Human Rights Council," Canadian Journal of Human Rights 2, No. 1 (2013): 1-38.

39 Kevin Boyle, “The United Nations Human Rights Council: Origins, Antecedents, and Prospects," in New Institutions for Human Rights Protection, ed. Kevin Boyle (Oxford: Oxford University Press, 2009), 11-49, here 24.

${ }^{40}$ Resolution No. 1235, adopted by the Economic and Social Council, 1967, June 6, UN Doc. E/4393 (1967), https://digitallibrary.un.org/record/214657/files/E_RES_1235\%28XLII\%29-EN.pdf, para 3.

41 Ibid., para 2 and para 5.

42 John Carey, "U.N. Response to Government Oppression," The International Lawyer 3, No. 1 (1968): 102-108.

${ }^{43}$ Marc Limon and Hilary Power, History of the United Nations Special Procedures Mechanism: Origins, Evolution and Reform (Vorsoix: Universal Rights Group, 2014), 5-6, https://www.universal-rights.org/wp-content/uploads/2015/02/URG_HUNSP_28.01.2015_page_by_page.pdf. 
definitely inverted the presumption in Article 2(7) of the Charter of the United Nations that UN bodies should not "intervene in matters which are essentially within the domestic jurisdiction of any state." 44 Commenting on the impact of Resolution 1235 twenty-five years later, Thomas Buergenthal, a former member of the UN Human Rights Committee, praised the Commission for "pierc[ing] the veil of state sovereignty ... allowing for human rights protection." 45

In 1967, the Commission membership had expanded to accommodate the many new states joining the UN. Now, with fourteen African and Asian member states and the added support of the twelve states from the Latin American and the Eastern European blocs that created alliances on an issue by issue basis, the Third World bloc could count on between $45 \%$ and $75 \%$ of the voting power on the Commission. From 1970 to 1980, around $8 \%$ of all Commission meetings focused on South Africa specifically. Counting meetings on the issues of racism and self-determination - issues which were proxies for attacking minority rule and apartheid in South Africa - the Commission cumulatively spent about a quarter of its time on apartheid. ${ }^{46}$ Given the strong opposition to apartheid that members of the Third World bloc had expressed in the UN prior to the expansion of the Commission and the passage of Resolution 1235, it is difficult to conceive that the Commission would have departed from its purely "promotional" mandate without the growing urgency of apartheid as an issue. Yet the structure of Resolution 1235 led some states to argue that the Sub-Commission should not investigate matters outside South Africa and other minority-ruled territories in southern Africa, even though significant racial discrimination existed in other African states. ${ }^{47}$ The 1235 procedure was bound to attract a degree of hostility. As Kevin Boyle observes, even though the Third World bloc had instigated the resolution, they proved as "reluctant as other states" for it to be used against them. ${ }^{48}$ As Boyle goes on to note, there was a particular hostility to using the mechanisms "engineered [to tackle] apartheid, colonialism and Israel" against states that were members of the Third World bloc. The final paragraph

${ }_{44}$ Charter of the United Nations, signed 1945, June 26, Article 2(7), https://www.un.org/en/sections/un-charter/chapter-i/index.html.

45 Thomas Buergenthal's remarks at the 87th Annual Meeting of the American Society of International Law (2 April 1993) quoted in Surya P. Subedi, "Protection of Human Rights through the Mechanism of UN Special Rapporteurs," Human Rights Quarterly, Vol. 33, No. 1 (1993): 202.

46 Jack Donnelly, "Human Rights at the United Nations 1955-85: The Question of Bias," International Studies Quarterly 32, No. 3 (1988): 275-303.

47 Warren Weinstein, "Africa's Approach to Human Rights at the United Nations," African Issues 6, No. 4 (1976): 14-21, here 19, doi: 10.1017/S1548450500000664.

48 Boyle, "The United Nations Human Rights Council," 27. 
of 1235 made it clear that ad-hoc study groups the Commission created would be nominally independent. ${ }^{49}$ Despite this notional independence, their creation was under the control of the Commission, which itself was under the control of the member states elected to it. This allowed voting blocs to be gate-keepers of who would be subject to the 1235 procedure.

\section{An Individual Petition Mechanism: The 1503 Procedure}

The individual complaints procedure, known as the 1503 procedure, allowed individuals to send the Commission petitions or communications detailing human rights abuses by their governments, which would then be discussed in confidence at the Sub-Commission's annual sessions in Geneva. ${ }^{50}$ The case for letting the Commission receive individual petitions had been made for many years, but ECOSOC had resisted granting it this kind of power. ${ }^{51}$ In July 1959, an ECOSOC resolution rejected allowing individual petitions, which were described by one contemporary source as "the most elaborate wastepaper basket ever designed." 52 Support for individual petitions changed after 1960, when more African and Asian states joined the General Assembly and sought election to the Commission. However, as Roland Burke notes, their support was limited to their "two main preoccupations ... apartheid and colonialism." 53 There was considerable support from the Third World bloc for allowing the Committee on Decolonization (the Committee of Twenty-Four) to hear petitions. Campaigning by the Committee of Twenty-Four on the issue of apartheid and decolonization led ECOSOC to reconsider accepting individual petitions. During the drafting process of resolution 1503, Tanzania tried unsuccessfully to introduce provisions that would require the Sub-Commission to focus exclusively on colonial

49 The control of the Commission over the agenda and consideration of the Sub-commission was already observed in 1967. See John P. Humphrey, "The United Nations Sub-Commission on the Prevention of Discrimination and the Protection of Minorities," The American Journal of International Law 62, No. 4 (1968): 869-888, here 886.

${ }^{50}$ For an overview of these procedures, see M. E. Tardu, "United Nations Response to Gross Violations of Human Rights: The 1503 Procedure," Santa Clara Law Review 20, No. 3 (1980): 559-602; Howard Tolley, "Decision Making at the United Nations Commission on Human Rights," Human Rights Quarterly 5, No. 1 (1983): 27-58.

${ }^{51}$ Louis Sohn, “The Improvement of the UN Machinery on Human Rights," International Studies Quarterly 23, No. 2(1979): 186-215, 202.

52 Humphrey, Human Rights and the United Nations, 28.

53 Roland Burke, Decolonization and the Evolution of International Human Rights (Philadelphia: University of Pennsylvania Press, 2009), 69. 
situations and apartheid. ${ }^{54}$ Other states from the Third World bloc, along with Eastern European states, were critical of allowing any individual petition procedure outside of South Africa. ${ }^{55}$ Most Third World bloc states on the Commission voted against the initial proposal for an individual petition mechanism for the Sub-Commission in 1968, but it passed the Commission by the narrowest of margins. ${ }^{56}$ It was only after a successful Tanzanian proposal to have communications be considered in confidence, increasing the power of the Commission over their handling, that many states from the Third World bloc became supportive of the new procedure. This proved important to its eventual passage in ECOSOC in 1970, when Third World bloc states refused to join the Eastern European states in bloc voting to oppose the resolution.

Patrick Flood argues that the 1503 procedure was "designed to provide a way for the Sub-Commission to evaluate situations amounting to consistent patterns of gross violations" of human rights. ${ }^{57}$ European human rights activists initially praised the 1503 procedure for providing a forum for individuals to petition against their governments' human rights abuses. Yet, the procedure, while it provided an extensive mechanism for the processing of individual complaints, did not make the communications it received public until the end of the process, when recommendations were transmitted to ECOSOC. Nor did it actually make the individual victim a party to the proceedings; as Tardu notes, under the 1503 procedure the individual "plaintiff is an information transmitter" and there was no entitlement to have their communication considered. ${ }^{58}$ The petitions were processed by an expert working group and then referred to the Sub-Commission for consideration - around six to eight petitions out of the hundreds received each year were processed during each Commission session. There was no mechanism for processing urgent petitions while the Sub-Commission was not in session. According to Tolley, this contributed to the Commission's failure to process complaints received about the Greek military junta in $1974 .{ }^{59}$ It was only in the final stage of consideration, after interstate dialogue had failed to yield results, that the substance of a communication could be made public by the Commission

54 Draft Resolution, E/CN.4/L.991/ Rev.1 (1968).

55 Patrick Flood, The Effectiveness of UN Human Rights Institutions (Westport, CT: Greenwood Publishing Group, 1998), 56.

56 Tolley, "United Nations Commission," 60.

57 Ibid.

58 Tardu, "United Nations Response," 562.

${ }^{59}$ Howard Tolley, "The Concealed Crack in the Citadel: The United Nations Commission on Human Rights' Response to Confidential Communications," Human Rights Quarterly 6, No. 3 (1984): $420-462$, here 441 . 
as a means of "shaming" the state in question for its human rights violations. ${ }^{60}$ In summary, the enforcement powers under the 1503 procedure were entirely dependent upon what Bertrand Ramcharan has described as bringing the "international presence to bear upon a situation." 61

Shaming and political pressure at the international level can sometimes be effective at triggering human rights reform in individual countries. The shaming institutionalized in the 1503 procedure was designed to pressure states into making reforms to address their human rights violations. ${ }^{62}$ However, for this to work it required the 1503 procedure to be applied consistently and to all states where human rights abuses were taking place. Consistency in the application of powers is an important factor in the development of the content-independent legitimacy of an international institution - the notion that an institution is itself legitimate, regardless of the results or outcomes of its decisions. ${ }^{63}$ The control that the Commission had over the 1503 process was applied in a manner that reflected the prevailing ideological consensus or collective interests of particular blocs. This control was enabled by the structure of Resolution 1503, which contained only one reference to "violations of human rights and fundamental freedoms" in its preamble and no other description of what would constitute behavior that would trigger consideration under the procedure. ${ }^{64}$ Attempts by the United States in 1968 to introduce a list of practices which constitute human rights violations into the text of the procedure - such as "torture" or "violation of freedom of expression" - were not formally adopted

60 "Procedure for Dealing with Communications Relating to Violations of Human Rights and Fundamental Freedoms," Resolution No. 1503 (XLVIII), adopted by the Economic and Social Council, 1970, May 27, UN Doc. E/4832/Add.1 (1970) (hereafter Resolution No. 1503) http://www .tebtebba.org/index.php/all-resources/category/140-2c-the-hr-council-and-its-subsidiary-bodies?download $=730$ :resolution-1503xlviii-of-the-economic-and-social-council.

${ }^{61}$ Bertrand Ramcharan, The Concept and Present Status of the International Protection of Human Rights: Forty Years After the Universal Declaration (Dordrecht: Kluwer Academic Publishers, 1989), 138.

62 Thomas Risse and Kathryn Sikkink, "The Socialization of International Human Rights Norms Into Domestic Practices: Introduction," in The Power of Human Rights: International Norms and Domestic Change, ed. Stephen C. Ropp, Thomas Risse, and Kathryn Sikkink (Cambridge: Cambridge University Press, 1999), 1-38.

63 Allen Buchanan and Robert O. Keohane, "The Legitimacy of Global Governance Institutions," Ethics \& International Affairs 20, No. 4 (2006): 405-437, doi: 10.1111/j.1747-7093.2006.00043.x; Steven Wheatley, "On the Legitimate Authority of International Human Rights Bodies," in The Legitimacy of International Human Rights Regimes: Legal, Political and Philosophical Perspectives, ed. Andreas Føllesdal, Johan Karlsson Schaffer, and Gier Ulfstein (Cambridge: Cambridge University Press, 2015): 84-116.

${ }^{64}$ Resolution 1503, Preamble. 
by the Sub-Commission and hence did not make it into the final draft of the ECOSOC resolution. ${ }^{65}$ This meant that the Commission could in effect interpret for itself what constituted a "violation" of human rights, as it was required to do under section 6 of the procedure for determining whether a violation was severe enough to require investigation or further action. ${ }^{66}$ When the Commission's membership was expanded in 1967, which as noted above increased the Third World bloc's overall voting power, the Third World bloc wielded greater interpretative control over the procedure, increasing support for it to be used in the anti-apartheid cause even though it was not specifically mentioned in Resolution 1503.

\section{How the Commission's Procedural Reforms Shaped its Politics}

The new legal structures of the UN, which were shaped by the Third World bloc's anti-apartheid pressure in the late 1960s, influenced the Commission's politics in the 1970s and early 1980s. During this time the politics of the Commission were criticized for being dominated by "double standards." A double standard means that different criteria are applied to situations which are so similar that they merit equal treatment. ${ }^{67}$ For example, Laurie Weisberg notes that at the Commission "no parallel was drawn between the exploitation of the Ethiopian peasant and the exploitation of the South Africa squatter," even though both were exploited by their governments and denied political rights. ${ }^{68}$ There was no obvious justification as to why human rights abuses committed by the Amin regime in Uganda were not worthy of the Sub-Committee's attention, especially when other racist regimes were under investigation. As Onyeonoro Kamanu noted in the mid-1970s, attempts to argue that human rights abuses committed by the governments of some newly independent states against their own populations were somehow distinct from human rights abuses committed by the white regime in South Africa often ended up implicitly defending intra-racial domination of one group over another. ${ }^{69}$

65 Tolley, "United Nations Commission," 60.

${ }^{66}$ Resolution 1503, Art 6.

${ }^{67}$ Laurie S. Wiseberg, "Human Rights in Africa: Toward the Definition of the Problem of a Double Standard," African Issues 6, No. 4 (1976): 3-13, here 5, doi: 10.1017/S1548450500000652.

68 Ibid., 67.

69 Onyeonoro S. Kamanu, "Secession and the Right of Self-Determination: An OAU Dilemma," The Journal of Modern African Studies 12, No. 3 (1974): 355-376. 
While the political forces at the Commission were frequently accused of applying "double standards," especially by contemporary commentators in the 1970 s and 1980 s, the term is too reductive. ${ }^{70}$ Instead, it makes sense to distinguish three inter-related arguments about the application of the 1235 and 1503 procedures that were made by some states in response to how the Commission exercised its new powers. All of these arguments were linked to the design of the 1235 and 1503 procedures. They shaped the political template of the Commission for the future.

\section{Restrictive Interpretation of the Commission's Powers}

The Commission's powers were interpreted in the context of defensiveness about sovereignty in the Third World bloc, resulting in changes to international human rights law and the institutions designed to protect them. Anti-colonial independence movements made frequent appeals for protection of human rights. In a 1959 speech, Julius Nyrere said that independence was a fight "for our rights as human beings," and that it was ludicrous to think that after independence Tanzanians were going to turn around and say "to hell with all this nonsense about human rights." ${ }^{1}$ Human rights served as a useful rallying point in anti-colonial struggles, but the power to investigate human rights abuses was not fully institutionalized in an organization. ${ }^{72}$ As Meredith Terretta notes, decolonization engineered a tension between human rights activists and the governments of their newly independent states, which were determined to cement their newly acquired political authority. ${ }^{73}$ Roland Burke observed that before and after the Bandung conference, representatives of Third World governments displayed little awareness of the "potential antagonism between rights and sovereignty." 74 At the first World Conference on Human Rights held in Tehran in 1968, states

${ }^{70}$ For further illustrative examples from the 1970s, see Dana D. Fischer, "The International Protection of Human Rights," Proceedings of the Academy of Political Science 32, No. 4 (1977): 44-55; Uganda \& Human Rights. Reports to the UN Commission on Human Rights, ed. International Commission of Jurists (Geneva: International Commission of Jurists, 1977).

${ }^{71}$ Julius K. Nyerere, "Individual Human Rights (September 1959)," in Freedom and Unity: Uhuru na Umoja (London: Oxford University Press, 1967), 70.

72 Meredith Terretta, "We Had Been Fooled into Thinking that the UN Watches over the Entire World': Human Rights, UN Trust Territories, and Africa's Decolonization," Human Rights Quarterly 34, No. 2 (2012): 329-360, doi: 10.1353/hrq.2012.0022.

${ }^{73}$ Meredith Terretta, "From Below and to the Left? Human Rights and Liberation Politics in Africa's Postcolonial Age," Journal of World History 24, No. 2 (2013): 389-416.

${ }^{74}$ Burke, Decolonization, 25. 
from the Third World bloc clearly associated defending their sovereignty with arguments about substantive reform of international human rights law. ${ }^{75}$

At the Commission, sovereignty was a more complex issue. Many states could agree that there were some states that no doubt deserved to be targeted by the 1235 and 1503 procedures. However, they were more cautious about the expansive use of any of the Commission's new powers. A number of states consistently objected to the 1503 procedure on the grounds that it expanded the powers of a UN body in a manner that was inconsistent with the purposes of the UN and the protection of state sovereignty. ${ }^{76}$ However, as Jakob Möller notes, the majority of states that were members of the Commission recognized that both procedures were "within the realm of Articles 55 and 56 of the [UN] Charter," which committed states to take action to achieve respect for fundamental principles such as human rights. ${ }^{77}$ That did not stop states from contesting the Commission's competence when it was in their interest to do so. During the 1970s, as the Commission and Sub-Commission began to accept individual cases for consideration, some states such as Pakistan, India, and Ethiopia argued for restrictive approaches to utilizing the Commission's powers. ${ }^{78}$ Other states from the Third World bloc, such as Senegal, were much more open to the Commission's use of its new powers. ${ }^{79}$ In 1981, the Brazilian representative maintained that the Sub-Commission lacked the authority to criticize nations for their human rights records and that the role of the Commission was simply to receive information. ${ }^{80}$ Article Six of Resolution 1503 does not explicitly give the Sub-Commission or the Commission the power to condemn states, and when it is read in tandem with Article Seven and Eight, which require investigative measures to be exercised in cooperation with the state in question and to keep any work confidential, it is hard to construct such a power. ${ }^{81}$

Yet, as Ton Gardeniers et al. have noted, by the early 1980s it was quite clear that the Commission had in effect adopted this understanding of its powers

75 Roland Burke, "From Individual Rights to National Development: The First UN International Conference on Human Rights, Tehran, 1968," Journal of World History 19, No. 3 (2008): 275-296.

76 Jakob Th. Möller, "Petitioning the United Nations," Universal Human Rights 1, No. 4 (1979): 57-72.

77 Ibid., 65.

78 David P. Forsythe, “The United Nations and Human Rights, 1945-1985," Political Science Quarterly 100, No. 2 (1985): 249-269, here 255-256, doi: 10.2307/2150655.

79 Ibid.

80 Ton Gardeniers, Hurst Hannum, and Janice Kruger, “The UN Sub-Commission on Prevention of Discrimination and Protection of Minorities: Recent Developments," Human Rights Quarterly 4, No. 3 (1982): 353-370, doi: 10.2307/762223.

${ }^{81}$ Resolution No. 1503. 
under its new procedures. ${ }^{82}$ This was not a phenomenon that was specific to the 1503 procedure and the Commission; theorists of international organizations have noted that institutional structures often evolve beyond the parameters originally anticipated by the states that designed them. ${ }^{83}$ This can especially happen when an organization has investigative or adjudicative functions. As Brian Simpson observes, it would have been a struggle to ratify the European Convention on Human Rights in the 1950s if states had foreseen a future where the European Court of Human Rights would be defined by its "intrusiveness into what were once viewed as purely domestic matters." ${ }^{84}$ Defending sovereignty, although it was a core argument in the Commission, was less important than arguments about where to apply the Commission's new-found powers. There was a reasonable consensus that human rights abuses ought to be investigated but a dispute about which states should be the subject of such investigations.

\section{Inter-bloc Shielding}

Many who write about the behavior of the Third World bloc have noted the collective solidarity between its member states. This solidarity served both an ideological function, in that it sought to project a set of shared values, and an instrumental function, providing newly independent states with a system of support in international organizations. ${ }^{85}$ Collective solidarity included what can be described as "inter-bloc shielding" - the use of formal mechanisms or rhetorical appeals to deflect or steer institutional procedures for protection of human rights away from fellow states in the same bloc. Rupert Emerson, writing in 1975, observed that systematic human rights abuses, such as the massacres in Rwanda in 1965 and forced deportations from Ghana, were overlooked, ignored and in some cases even defended by the Third World bloc at the Commission. ${ }^{86}$ Delegates from the Third World bloc blocked discussion of discriminatory practices

\footnotetext{
82 Gardeniers, Hannum, and Kruger, "UN Sub-Commission.”

83 Andrew Guzman, "International Organizations and the Frankenstein Problem," European Journal of International Law 24, No. 4 (2013): 999-1025, doi: 10.1093/ejil/cht061.

${ }^{84}$ Brian Simpson, Human Rights and the End of Empire: Britain and the Genesis of the European Convention on Human Rights (Oxford: Oxford University Press, 2001), 4.

85 See for illustration: S. D. Muni, “The Third World: Concept and Controversy," Third World Quarterly 1, No. 3 (1979), 119-128; Steven K. Holloway and Rodney Tomlinson, "The New World Order and the General Assembly: Bloc Realignment at the UN in the Post-Cold War World," Canadian Journal of Political Science/Revue canadienne de science politique 28, No. 2 (1995): 227-254.

86 Rupert Emerson, "The Fate of Human Rights in the Third World," World Politics 27, No. 2 (1975): 201-226.
} 
in Ghana and Tanzania by the Sub-Commission. ${ }^{87}$ This did not necessarily mean that states were always successful in blocking consideration of communications from citizens of Third World states. For example, in 1977 the Sub-Commission considered a petition from Jehovah's Witnesses in Malawi alleging that the government was attempting to ban them from practicing their religion. The Commission first received petitions alleging serious human rights abuses in Equatorial Guinea in 1974, which the Sub-Commission considered in confidence in 1975. But the skepticism of some states in the Commission delayed further action on the subject for over two years, during which time the Macias Nguema regime went on what can only be described as an unconstrained killing spree. ${ }^{88}$ Eventually, in 1978, the Commission went public with some of the complaints that it had received from petitioners in states of the Third World bloc such as Ethiopia, Indonesia, Malawi and Equatorial Guinea. But there was little doubt, as Kevin Boyle noted, that bloc voting by members of the Commission was "restricting and frustrating its work." 89

The ability of the Commission to control the use of 1235 and 1503 procedures was only part of the picture when it came to inter-bloc shielding. More important were structural ambiguities in the instruments themselves. There was doubt about whether the express references to apartheid in 1235 were only examples of situations where the Commission could act or actual constraints on the Commission's power. Inter-bloc shielding actively supported the latter interpretation of the 1235 and a narrow interpretation of the situations where the 1503 procedure applied. When Uganda's forcible expulsion of its Asian community came before the Sub-Commission in 1972, the Nigerian delegate to the Commission attempted to block consideration of it, arguing that the situation "was not a human rights abuse." 90 A number of Commission delegates argued that they should not concern themselves with matters outside South Africa and other minority-ruled states, even though what was going on in Uganda was in fact systemic racial discrimination of the sort that the Sub-Commission had a direct mandate to investigate. ${ }^{91}$ In March 1977, the Sub-Commission was forced to abandon an investigation into systematic human rights abuses in Uganda, including the activities of government-sponsored death squads, in the face of political

\footnotetext{
87 Weinstein, “Africa's Approach.”

88 Randall Fegley, “The UN Human Rights Commission: The Equatorial Guinea Case," Human Rights Quarterly 3, No. 1 (1981): 34-47, doi: 10.2307/762065.

89 Boyle, "The United Nations Human Rights Council," 19.

90 Weinstein, "Africa's Approach," 18.

91 Ibid.
} 
resistance from other African members of the Commission. ${ }^{92}$ After a group of Nordic countries proposed a General Assembly resolution condemning Uganda in 1978, African states from the Third World bloc negotiated a compromise - the resolution would not be debated or put to a vote and the situation was referred back to the Sub-Commission for investigation. ${ }^{93}$

\section{The Identification of "Certain States" for Criticism}

Control of the Commission's agenda and blocking maneuvers in respect of the 1235 process were used not only to protect some states from criticism but also to single out certain states as human rights violators. Between 1967 and 1974, only South Africa and Israel were the subjects of direct action under the 1235 procedure ${ }^{94}$ Even there, care was taken to focus only on the situation within those two states and not on wider human rights issues. In a 1968 debate on Israeli policies in the occupied Palestinian territories, the executions of dissidents in other countries, such as Iraq, were rejected by States from the Third World bloc as being purely domestic matters and outside the scope of the Commission. The singling out of certain states (and exclusion of others) was a reflection of Cold War politics in many cases. In 1969, Morris Abram recalled one delegate to the Commission (from an unnamed state) saying, "we'd like to condemn the Soviet Union for its repression of intellectuals; we'd like to condemn the United States because of Vietnam ... we cannot afford to do either so we'll support a condemnation of Israel." 95 During the 1970s, this state of affairs only escalated. Some states were protected by their parent bloc; the United States, for example, insisted on changing the Commission's approach to the right-wing regime in Argentina because of its Cold War concerns. ${ }^{96}$

The advancement by the Commission of Third World priorities in other areas, such as economic and social justice, led to claims during the 1970s by Western powers (and from the United States in particular) that the Commission

92 Richard H. Ullman, "Human Rights and Economic Power: The United States versus Idi Amin," Foreign Affairs 56, No. 3 (1978): 529-543.

93 Ibid.

94 Complaints about other states were raised in debates. See Henning Boekle, "Western States, the UN Commission on Human Rights, and the '1235 Procedure': the 'Question of Bias' Revisited," Netherlands Quarterly of Human Rights 13, No. 4 (1995): 367-402, doi: 10.1177/016934419501300402.

95 Morris Abram, "The U.N. and Human Rights," Foreign Affairs 47, No. 2 (1969): 363-374, here 366.

96 Sandy Vogelgesang, "Diplomacy of Human Rights," International Studies Quarterly 23, No. 2 (1979): 216-245. 
was becoming "politicized." ${ }^{97}$ Arguments about politicization ultimately favored a narrow, American-backed "functionalist" view of international organizations, which held that the Commission's competencies should be confined to the powers it was originally granted by the states that created it. ${ }^{98}$ This would have meant rolling back the procedural innovations the Third World bloc had introduced. Accusations of double standards at the Commission provided cover for both the United States and the United Kingdom to dismiss the Commission's actions and resist attempts to develop even more anti-apartheid international legal instruments in the late 1970s. Their stance may also have been a reflection of pro-apartheid sympathies among some in the governments of those states. During the Reagan administration in the 1980s, criticism that the Commission was "anti-Western" grew in strength. Many critics cited the growing power of the Third World bloc as proof. ${ }^{99}$ This was, however, deeply cynical, because at the same time the United States advanced this criticism, it was openly supporting authoritarian anti-communist regimes in Latin America. Jeane Kirkpatrick, U.S. Ambassador to the UN, went so far as to praise authoritarian regimes that left "in place existing allocations of wealth, power [and] status" and were as a consequence "more compatible with U.S. interests." 100

By the early 1980s, double standards at the Commission were evidently infuriating some UN officials. In a 1982 address to the 38th session of the Commission, the Director of the UN Human Rights Division, Theo van Boven, said that he found it "unacceptable ... [that a] gross violation of human rights in any country should not be discussed ... simply because other situations have not been taken up as well." 101 It was clear that the Commission could only act in the case of an individual country when that country did not belong to any of the different competing blocs. For example, the right-wing regime in Chile became increasingly isolated from some of the major powers at the UN. The Third World

97 Gene M. Lyons, David A. Baldwin, and Donald W. McNemar, "The 'Politicization' Issue in the UN Specialized Agencies," Proceedings of the Academy of Political Science 32, No. 4 (1977): 81-92, doi: $10.2307 / 1173993$.

98 Ibid., 83.

${ }^{99}$ For an example of contemporary right-wing criticism, see Arieh Eilan, The General Assembly: Can It Be Salvaged (New York: Heritage Foundation, 1984). For a historical assessment, see Paul Kennedy, The Parliament of Man: The Past, Present, and Future of the United Nations (London: Penguin Books, 2006), 188-191.

100 Jeane Kirkpatrick, Dictatorships and Double Standards: Rationalism and Reason in Politics (New York: Simon and Schuster, 1982).

101 Address at the 38th session of Commission on Human Rights, Geneva 1 February 1982 in Thomas M. Franck, "Of Gnats and Camels: Is there a Double Standard at the United Nations?" American Journal of International Law 78, No. 4 (1984): 811-833, here 828, doi: 10.2307/2202197. 
bloc have much sympathy with the Pinochet regime, because it had alienated itself from pro-Third World regimes in the Latin American region. ${ }^{102}$ From 1981 to 1985 , the Commission issued a series of resolutions singling out Iran and Kampuchea (Cambodia), two states that had previously been defended by the Third World bloc, for engaging in systemic human rights abuses. However, this may have been a reflection of those states' specific internal politics rather than a change in the attitude of any of the blocs. The process of considering cases under the 1503 procedure remained in thrall to inter-bloc shielding. ${ }^{103}$ Some states were able to escape consideration in confidential sessions altogether: from 1984 onwards Pakistan was highlighted as a cause for concern at Commission meetings but it managed to escape referral to the Sub-Commission for action for years. In a particularly grisly coincidence, in 1988 the Commission halted an investigation of Iraq under the 1503 procedure just four days before Saddam Hussein's government launched a nerve gas attack on Iraq's Kurdish minority. ${ }^{104}$

\section{Conclusion: The Long-term Impact on the Commission}

By the end of the 1980s, the number of debates about apartheid decreased at the Commission as the South African regime began to collapse. However, the basic structure of politics at the Commission, with certain states being singled out for human rights criticism and others benefiting from inter-bloc shielding, began to evolve. In 1992, when the Commission again expanded in size, bloc voting continued to result in division. Condemnation of Cuba and Israel divided different factions. In the mid-1990s, disagreements over whether racism occurred in all societies or just in western societies sparked arguments about the mandate of the Commission's Special Rapporteur on Contemporary Forms of Racism, Racial Discrimination, and Xenophobia. ${ }^{105}$ China was able to end the 1990 s without ever having been subjected to a 1503 procedure. The United States defended Israel, but Israel was targeted by all other states. The independence of the Sub-Commission and the legitimacy of both its procedures was increasingly

102 Theo van Boven, "United Nations and Human Rights, A Critical Appraisal," in UN Law/Fundamental Rights: Two Topics in International Law, ed. Antonio Cassese (Berlin: Springer, 1979), 127-147.

103 See Franck, "Of Gnats and Camels."

104 David Weissbrodt, "Country-Related and Thematic Developments at the 1988 Session of the UN Commission on Human Rights," Human Rights Quarterly 10, No. 4 (1988): 544-558, here 550, doi: $10.2307 / 761920$.

105 Beate Rudolf, "The Thematic Rapporteurs and Working Groups of the United Nations Commission on Human Rights," Max Planck Yearbook of United Nations Law 4 (2000), 289-329, here 319. 
questioned. ${ }^{106}$ By 2006, eventual replacement of the Commission by the creation of a new UN Human Rights Council was seen by many commentators and scholars as the best response to the Commission's credibility problems. ${ }^{107}$ However, criticism of the Commission's "politicization" in the 1990s missed the point. ${ }^{108}$ All human rights, and human rights institutions, are political because creating an instrument to protect rights involves deciding which rights to protect and which rights not to protect. ${ }^{109}$ The politicization of the UN Commission on Human Rights was structural. It originated in the way the 1235 and the 1503 procedures were designed in the 1960s and used in the 1970s. Applying the analytical framework of rational design - described in the introduction to this article - two features of the procedures highlight how the Third World bloc understood the politics of protecting human rights.

Firstly, both the 1235 and 1503 procedures reflected what is sometimes termed an "idiographic political assumption" about the roles of international law and international institutions. Commitment to and support for the 1235 and 1503 procedures demonstrated the social identity of the states that created them. ${ }^{110}$ In the case of the 1235 and 1503 procedures, condemning apartheid was part of the social identity of the newly independent states of Africa and Asia in the international sphere. Therefore, they were keen to support any institutional development that would undermine apartheid. What was less clear, however, was whether the scope of their political commitment included a broader commitment, either to the Commission as an institution or to human rights protection in general. During the debates in the drafting process of major human rights treaties such as the ICCPR in the 1960s, some of the same states that supported the 1235 and 1503 procedures opposed the development of the

106 Michael Dennis, “The Fifty-Fourth Session of the UN Commission on Human Rights," The American Journal of International Law 93, No. 1 (1999): 246-252, doi: 10.2307/2997970.

107 Philip Alston, "Reconceiving the UN Human Rights Regime: Challenges Confronting the New UN Human Rights Council," Melbourne Journal of International Law 7, No. 1 (2006): 186-225, doi: 10.2139/ssrn.907471; Thomas G. Weiss, What's Wrong with the United Nations and How to Fix It, 2nd ed. (London: Polity Press, 2012), 40.

108 Jean-Claude Buhrer, "UN Commission on Human Rights Loses All Credibility: Wheeling and Dealing, Incompetence and 'Non-Action'," July 2003, Reporters Without Borders, https://rsf.org /fr/actualites/un-commission-human-rights-looses-all-credibility-wheeling-and-dealing -incompetence-and-non-action.

109 Jean-Luc Nancy, "On Human Rights: Two Simple Remarks," in The Meanings of Rights: The Philosophy and Social Theory of Human Rights, ed. Costas Douzinas and Conor Gearty (Cambridge: Cambridge University Press, 2014), 15-38, doi: 10.1017/CBO9781139227124.003.

110 Christian Reus-Smit, "Politics and International Legal Obligation," European Journal of International Relations 9, No. 4 (2003): 591-625, here 610, doi: 10.1177/135406610394003. 
individual petition procedure. ${ }^{111}$ In 1977, Patrick Flood noted that Third World bloc states opposed the creation of a UN High Commissioner for Human Rights, after Soviet bloc countries actively lobbied them against the idea, "[playing] on ... sensitivities concerning their colonial past [in order] to portray the High Commissioner proposal as a neo-colonial Trojan Horse."112 In the 1980s, Manfred Nowak noted that despite a growing international consensus to oppose the use of torture, many states from the Third World bloc actively opposed setting up a Committee Against Torture. ${ }^{113}$ More powerful states, such as the Soviet Union (later Russia) and the United States, were also strongly opposed to any individual petition mechanism in principle, and only strategically supported such mechanisms when they would operate in their interests.

Secondly, there was the broader problem of how to construct an institutional mechanism that could engineer the naming and shaming of a state in which human rights abuses were taking place, commanding the support of other member states. At the regional level, international human rights protection regimes emerged in tandem with international organizations built around projects of political or economic integration. Organizations based on the latter type of political project offered different incentives to states in order to gain their initial commitment and acceptance of the organization's power to protect human rights. ${ }^{114}$ At the international level, many states viewed the bodies set up by human rights treaties such as the ICCPR as mechanisms for externally signaling their commitment to human rights. For example, there was a surge in the number of states signing up to human rights treaties during the so-called "third wave of democracy" in the 1990s. ${ }^{115}$

For a body with a politicized membership tasked with overseeing investigative procedures, as was the Commission with its oversight responsibility for the Sub-Commission, the issue was how to survive in a world where the question of who is a human rights victim was always going to be a politically contested

111 Burke, Decolonization, 72.

112 Patrick J. Flood, The Effectiveness of UN Human Rights Institutions (Westport, Connecticut: Greenwood Publishing Group 1998), 120.

113 Manfred Nowak, "The Attitude of Socialist States towards the Implementation of UN Human Rights Conventions,” Netherlands Human Rights Quarterly 6, No. 2 (1987): 85-90.

114 B. Obinna Okere, "The Protection of Human Rights in Africa and the African Charter on Human and Peoples' Rights: A Comparative Analysis with the European and American Systems," Human Rights Quarterly 6, No. 2 (1984): 141-159.

115 Christine Min Wotipka and Kiyoteru Tsutsui, "Global Human Rights and State Sovereignty: State Ratification of International Human Rights Treaties, 1965-2001,” Sociological Forum 23, No. 4 (2008): 724-754, doi: 10.1111/j.1573-7861.2008.00092.x. 
concept. This is the dilemma set out by Makau Mutua in the influential paper "Savages, Victims, Saviours." Mutua argues that the concept of human rights is caught up in a "grand narrative" which uses institutional forms and structures to create and identify classes of human rights victims who are under attack by "savages" within their own society. ${ }^{116}$ Reform of the Commission in the 1960 s took place in the context of directly targeting apartheid in South Africa and preserving post-independence self-determination for former colonies. From the perspective of the Third World bloc, the "victims" and "savages" implicit in the 1235 and 1503 procedure only included those suffering under the apartheid regime. The wording of both instruments encouraged this interpretation. They were not worded in a way that supported a broader concept of victimhood that would encompass all targets of governmental human rights abuses.

Double standards, as they were called, were a function of the way that the 1235 and 1503 procedures were designed, because the references to apartheid in them could easily be interpreted as exclusionary. The control that both procedures gave to the Commission was an incentive for blocs of states to seek Commission membership in order to control those procedures and defend their member states and their allies in other blocs from human rights scrutiny. In December 2004, the High-level Panel on Threats, Challenges and Change, which was tasked with evaluating existing UN institutions, concluded that too many states were seeking membership of the Commission "not to strengthen human rights but to protect themselves against criticism or to criticize others." 117 As one 2008 study concluded, during the last decade of the Commission's existence, states with weak human rights records were more likely to get elected to the Commission than those with strong ones. ${ }^{118}$ None of these developments emerged in a vacuum. They were intimately linked with the way the Commission's powers had been designed in the late 1960s. The campaign against South African apartheid was a powerful catalyst for institutional reform and development of human rights law, but some of the changes made at the time were expressly tied into the context of apartheid. Conflict over whether they were intended to usher in a broader-based set of institutional reforms cemented a politics of human rights at the Commission that ultimately led to its dissolution and replacement.

116 Makau Mutua, "Savages, Victims, and Saviors: The Metaphor of Human Rights," Harvard International Law Journal 42, No. 1 (2001): 201-245.

117 Ibid.

118 Martin S. Edwards et al., "Sins of Commission? Understanding Membership Patterns on the United Nations Human Rights Commission,” Political Research Quarterly 61, No. 3 (2008): 390-402. 